$\sqrt{3}$

J. Bio-Sci. 26: 41-48, 2018

ISSN 1023-8654

http://www.banglajol.info/index.php/JBS/index

\title{
ISOLATION AND CHARACTERIZATION OF AERIAL BACTERIA FROM A MICROBIOLOGY LABORATORY ENVIRONMENT
}

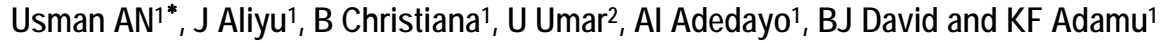 \\ ${ }^{1}$ Department of Microbiology, Federal University of Technology, Minna, Niger State, Nigeria \\ ${ }^{2}$ Department of Biological Science, Abubakar Tafawa Balewa, University, Bauchi State, Nigeria
}

\begin{abstract}
Sterile nutrient agar (NA) plates were exposed to the inner and outer environment of the laboratory for 15 minutes before the commencement of laboratory work in the morning and after closure of activities in the evening after which the plates were incubated at $37^{\circ} \mathrm{C}$ for 24 hours. Antibiotic susceptibility of the bacterial isolates was done using agar well diffusion technique. The aerial bacterial load outside the laboratory was found to be higher than inside the laboratory. Bacteria isolated include members of the genus Staphylococcus, Bacillus, Lactobacillus, Salmonella, Micrococcus, Streptococcus, Proteus and Escherichia. Bacillus subtilis had the highest frequency of occurrence $(31.0 \%)$ followed by alpha haemolytic streptococcus (19.0\%) while the least frequency of occurrence was shown by Proteus bulgaricus and Proteus species (1.7\%). All the bacteria were sensitive to antibiotics tested except Micrococcus luteus. They were equally found to be sensitive to the anti-microbial agent (antiseptic and disinfectant) tested except for the hand sanitizer to which most isolates displayed high resistance. The presence of a wide variety of pathogenic microorganisms in the laboratory shows that the environment requires regular cleaning and disinfection to enhance the safety of staff and students using the laboratory.
\end{abstract}

Key words: Agar, Aerial, Bacteria, Indigenous, Isolation

\section{Introduction}

Air contains tiny organisms such as fungi, bacteria, and viruses. Microorganisms are distributed everywhere in the environment surrounding us. The concern about the microbiological quality of the air whether indoor or outdoor has increased over the years because of its significant contribution to public health (Douwes et al. 2003). There are no indigenous microbes in the air, microbes found in air are transported through wind and human activities. The composition and concentration of these organisms in air reflect the nature of human's activities such as sneezing, coughing, yawning, farming, sweeping, industrial processes and so on (Adams et al. 2014, Prussin and Marr 2015). Atmospheric pollution poses serious challenges and is one of the major sources of public health problems of our time. Increased levels of airborne microorganisms have a very high chance of causing infectious diseases (Den Boer et al. 2002). Ironically, this pollution is on the increase making it a threat to the health and well-being of the people (Ekhaise et al. 2008) that requires periodic investigation.

Some other sources have also been found to be responsible for the presence of microorganisms found in the air. One of the most common sources of air micro flora is the soil. When soil is disturbed by the wind, free living microbes and their spores are blown into the air and may remain suspended in the air for a long period

*Author for correspondence: nasiru.adabara@futminna.edu.ng 
of time. Human activities like digging, ploughing the soil also release soil borne microbes into the air. Microorganisms found in water may also be released into the air in form of water droplets or aerosols. Water splash by wind or tidal action may also produce droplets or aerosols. Air currents may transport microbes from plants and animals surfaces into the air (Burge et al. 1982). Air, unlike soil and water is an unfavorable environment for microorganisms because there are limited nutrients. Moisture content needed for microbial growth is infrequently minimal and survival rate is often low as they are always on transit as a result of wind action. The atmosphere is exposed to sunlight and radiation as a result of which the moisture content is low accompanied by high temperature. If the microbes are not protected from desiccation in the form of spores, they soon die (Nocker et al. 2012). For the microbes to survive in air for a longer time, they need to be protected from direct radiation. However, the short time these microbes spend in air are usually sufficient in many cases to gain access to human and animal hosts.

Air serves as a means of dispersal for microorganisms. The spores of bacteria, fungi, algae, viruses and protozoan cyst in the air can transmit disease from one individual to another. Chicken pox, influenza, measles, small pox, tuberculosis are diseases transmitted by air (Mitchell et al. 1994). Upper respiratory airways inflammation such as coughing, sinus congestion and sore throats are caused by airborne agents (Piters et al. 2015, Solomon et al. 2017). However, many of the bacteria in the air with which people are in regular contact are infrequent causes of human illnesses, even though some may serve as causes of hypersensitivity (Tsai and Macher 2005). Since there are no indigenous microbes in the air, their presence in air is as a result of wind action and human activities. Too much inhalation of the microbes especially the pathogenic ones can be harmful (Naruka and Gaur 2014). Therefore, there is a need to investigate the microbial quality of air in human environments particularly laboratories where microorganisms are handled on daily basis.

\section{Materials and Methods}

\section{Preparation of media}

All the media used (Nutrient Agar (NA), Blood Agar (BA), Mannitol Salt Agar (MSA) and Starch Agar (SA) were prepared according to the manufacturer's instructions.

\section{Isolation of microorganisms}

Sterile plates containing NA were exposed in the laboratory at three different heights (on the ground, on the bench and close to the ceiling) in the morning before the commencement of laboratory activities for 15 minutes. This procedure was repeated in the evening after the day's activities including outside the laboratory. At the end of each exposure periods, the plates were incubated at $37^{\circ} \mathrm{C}$ for 24 hrs. Primary growths were sub-cultured on fresh NA, MSA and BA plates and were further incubated at $37^{\circ} \mathrm{C}$ for 24 hours to obtain pure cultures. The pure cultures of bacteria obtained were maintained on slant and stored on NA in a refrigerator $\left(4-8^{\circ} \mathrm{C}\right)$.

\section{Characterization and identification of bacterial isolates}

The identification and characterization of bacterial isolates were carried out as described by Cowan and Steel (1974), and Holdbrook (1982). The colonial morphology of the growth was examined and characteristics colonies were identified using microscopic technique and biochemical tests as described by Cheesbrough (2009). 


\section{Antimicrobial agents (antiseptics and disinfectants) susceptibility test}

The susceptibility test was carried out using agar well diffusion method as described by Cheesbrough (2009). The isolates from the slant were standardized and swabbed on surface of NA. A sterile cork borer of $5 \mathrm{~mm}$ diameter was used to bore holes on the culture plate. Molten sterile NA was used to seal the bottom of the hole created, $0.2 \mathrm{ml}$ each of $70 \%$ of Izal, dettol, alcohol, hypochlorite and hand sanitizer was introduced into each hole and allowed to stay for $1 \mathrm{hr}$. The plates were then incubated at $37^{\circ} \mathrm{C}$ for $24 \mathrm{hrs}$. Zones of inhibition observed for each of the susceptible isolates were measured and recorded using standard procedures.

\section{Results}

Wide ranges of bacterial isolates were obtained following the exposure of culture media plates at different height (on the ground, on the bench and close to the ceiling) inside and outside the Microbiology Laboratory. They were identified as species of the genus Staphylococcus, a-haemolytic Streptococcus, Bacillus, Micrococcus, Lactobacillus, Salmonella, Escherichia and Proteus. Microbial load of isolates from outside the laboratory were more compared to isolates from inside the laboratory (Table 1). Organisms isolated from within the laboratory in the morning and outside the laboratory were gram positive bacteria while those isolated in the evening were a mixture of both gram positive and gram negative bacteria (Table 2). B. subtilis was sensitive to all antibiotics used while M. luteus was resistance to all except ciprofloxacin (Table 4). E. coli was sensitive to all the antibiotics while $P$. vulgaris was resistant to all. All the isolates were susceptible to the antimicrobial agents (izal and dettol) but were all resistant to the hand sanitizer (Table 1, 2, 3 and 4).

\section{Frequency of occurrence of bacterial isolates}

The bacteria isolated from inside and outside the laboratory occurred in different percentages with $B$. subtilis having the highest occurrence of $31.0 \%$ followed by a - haemolytic Streptococcus having $19.0 \%$, S. aureus, Staphylococcus sp., Lactobacillus sp. and M. luteus have $8.6 \%$, M. roseus 6.9\%, E. coli and Salmonella sp. $3.4 \%$ while $P$. vulgaris and Proteus sp. have the least percentage occurrence of 1.7\% (Table 2).

Table 1. Total viable count of bacterial isolates

\begin{tabular}{|c|c|c|c|}
\hline \multirow[t]{2}{*}{ Location } & \multicolumn{2}{|c|}{ Inside of the Laboratory } & \multirow{2}{*}{$\begin{array}{c}\text { Outside of the Laboratory } \\
\text { Evening }\end{array}$} \\
\hline & Morning & Evening & \\
\hline A (on the ground) & $28 \mathrm{cfu} / 15 \mathrm{~min}$. & 92 cfu/15 min. & $228 \mathrm{cfu} / 15 \mathrm{~min}$. \\
\hline $\mathrm{B}$ (on the bench) & $30 \mathrm{cfu} / 15 \mathrm{~min}$. & $61 \mathrm{cfu} / 15 \mathrm{~min}$ & - \\
\hline C (close to the ceiling) & 49 cfu/15 min. & $112 \mathrm{cfu} / 15 \mathrm{~min}$ & $136 \mathrm{cfu} / 15 \mathrm{~min}$. \\
\hline
\end{tabular}


Table 2. Summary of the frequency of occurrence of bacterial isolates

\begin{tabular}{|c|c|c|c|c|c|c|c|c|}
\hline \multicolumn{7}{|c|}{ Inside the Laboratory } & \multicolumn{2}{|c|}{ Outside the Laboratory } \\
\hline & \multicolumn{2}{|c|}{ Morning } & \multicolumn{3}{|c|}{ Evening } & \multirow[b]{2}{*}{ C } & \multirow[b]{2}{*}{ A } & \multirow[b]{2}{*}{ C } \\
\hline Bacteria & A & B & C & A & B & & & \\
\hline B. subtilis & $0(00.0)$ & $\begin{array}{c}3 \\
(60.0)\end{array}$ & $\begin{array}{c}5 \\
(71.4)\end{array}$ & $1(14.3)$ & $\begin{array}{c}0 \\
(00.0)\end{array}$ & $4(36.4)$ & $\begin{array}{c}3 \\
(30.0)\end{array}$ & $\begin{array}{c}2 \\
(28.6)\end{array}$ \\
\hline S. aureus & $1(20.0)$ & $\begin{array}{c}0 \\
(00.0)\end{array}$ & $\begin{array}{c}0 \\
(00.0)\end{array}$ & $1(14.3)$ & $\begin{array}{c}0 \\
(00.0)\end{array}$ & $1(9.10)$ & $\begin{array}{c}1 \\
(10.0)\end{array}$ & $\begin{array}{c}1 \\
(14.3)\end{array}$ \\
\hline S. sp. & $2(40.0)$ & $\begin{array}{c}1 \\
(20.0)\end{array}$ & $\begin{array}{c}0 \\
(00.0)\end{array}$ & $0(00.0)$ & $\begin{array}{c}0 \\
(00.0)\end{array}$ & $0(00.0)$ & $\begin{array}{c}2 \\
(20.0)\end{array}$ & $\begin{array}{c}0 \\
(00.0)\end{array}$ \\
\hline $\begin{array}{l}\text { a-haemolytic } \\
\text { Streptococcus }\end{array}$ & $0(00.0)$ & $\begin{array}{c}0 \\
(00.0)\end{array}$ & $\begin{array}{c}1 \\
(14.3)\end{array}$ & $0(00.0)$ & $\begin{array}{c}4 \\
(66.7)\end{array}$ & $3(27.3)$ & $\begin{array}{c}1 \\
(10.0)\end{array}$ & $\begin{array}{c}2 \\
(28.6)\end{array}$ \\
\hline $\begin{array}{l}\text { Lactobacillus } \\
\text { sp. }\end{array}$ & $0(00.0)$ & $\begin{array}{c}1 \\
(20.0)\end{array}$ & $\begin{array}{c}0 \\
(00.0)\end{array}$ & $1(14.3)$ & $\begin{array}{c}1 \\
(16.7)\end{array}$ & $1(9.1)$ & $\begin{array}{c}1 \\
(10.0)\end{array}$ & $\begin{array}{c}0 \\
(00.0)\end{array}$ \\
\hline M. roseus & $1(20.0)$ & $\begin{array}{c}0 \\
(00.0)\end{array}$ & $\begin{array}{c}0 \\
(00.0)\end{array}$ & $0(00.0)$ & $\begin{array}{c}1 \\
(16.7)\end{array}$ & $0(00.0)$ & $\begin{array}{c}1 \\
(10.0)\end{array}$ & $\begin{array}{c}1 \\
(14.3)\end{array}$ \\
\hline M. luteus & $1(20.0)$ & $\begin{array}{c}0 \\
(00.0)\end{array}$ & $\begin{array}{c}1 \\
(14.3)\end{array}$ & $1(14.3)$ & $\begin{array}{c}0 \\
(00.0)\end{array}$ & $0(00.0)$ & $\begin{array}{c}1 \\
(10.0)\end{array}$ & $\begin{array}{c}1 \\
(14.3)\end{array}$ \\
\hline E. coli & $0(00.0)$ & $\begin{array}{c}0 \\
(00.0)\end{array}$ & $\begin{array}{c}0 \\
(00.0)\end{array}$ & $1(14.3)$ & $\begin{array}{c}0 \\
(00.0)\end{array}$ & $1(9.1)$ & $\begin{array}{c}0 \\
(00.0)\end{array}$ & $\begin{array}{c}0 \\
(00.0)\end{array}$ \\
\hline P. vulgaris & $0(00.0)$ & $\begin{array}{c}0 \\
(00.0)\end{array}$ & $\begin{array}{c}0 \\
(00.0)\end{array}$ & $1(14.3)$ & $\begin{array}{c}0 \\
(00.0)\end{array}$ & $0(00.0)$ & $\begin{array}{c}0 \\
(00.0)\end{array}$ & $\begin{array}{c}0 \\
(00.0)\end{array}$ \\
\hline Proteus sp. & $0(00.0)$ & $\begin{array}{c}0 \\
(00.0)\end{array}$ & $\begin{array}{c}0 \\
(00.0)\end{array}$ & $0(00.0)$ & $\begin{array}{c}0 \\
(00.0)\end{array}$ & $1(9.1)$ & $\begin{array}{c}0 \\
(00.0)\end{array}$ & $\begin{array}{c}0 \\
(00.0)\end{array}$ \\
\hline Salmonella sp. & $0(00.0)$ & $\begin{array}{c}0 \\
(00.0)\end{array}$ & $\begin{array}{c}0 \\
(00.0)\end{array}$ & $1(14.3)$ & $\begin{array}{c}0 \\
(00.0)\end{array}$ & $1(9.1)$ & $\begin{array}{c}0 \\
(00.0)\end{array}$ & $\begin{array}{c}0 \\
(00.0)\end{array}$ \\
\hline Total bacteria & 5 & 5 & 7 & 7 & 6 & 11 & 10 & 7 \\
\hline
\end{tabular}

Values in parenthesis represent the percentage of isolates obtained. A (on the ground), B (on the bench), C (close to the ceiling) 
Table 3. Summary of antibiotics susceptibility of bacterial isolates

\begin{tabular}{|c|c|c|c|c|c|c|c|c|c|c|c|}
\hline 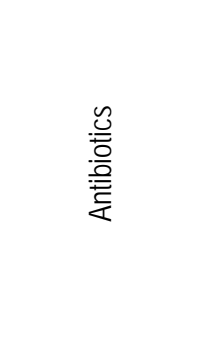 & 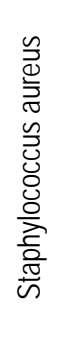 & 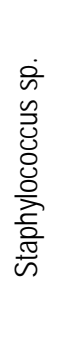 & 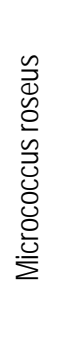 & 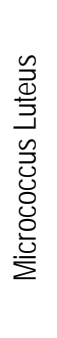 & 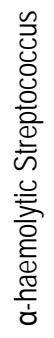 & 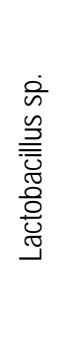 & 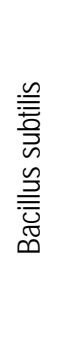 & 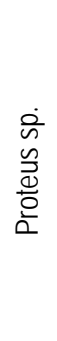 & $\begin{array}{l}\frac{n}{\pi} \\
\frac{\sigma}{3} \\
\vdots \\
0\end{array}$ & $\begin{array}{l}\bar{\circlearrowright} \\
\text { نे }\end{array}$ & $\frac{\dot{D}}{\infty}$ \\
\hline Pefloxacin & + & + & + & - & + & - & + & - & - & + & + \\
\hline Gentamycin & + & + & + & - & + & + & + & + & - & + & - \\
\hline Ampiclox & - & - & - & - & + & - & + & - & - & - & - \\
\hline Zinnacef & - & - & - & - & + & - & + & - & - & - & - \\
\hline Amoxacillin & - & - & - & - & + & - & + & - & - & + & - \\
\hline Rocephin & - & - & - & - & - & - & + & - & - & - & - \\
\hline Ciprofloxacin & + & + & + & + & + & + & + & + & - & + & + \\
\hline Streptomycin & + & + & + & - & - & + & + & - & - & + & - \\
\hline Septrin & + & - & + & - & + & - & + & - & - & + & - \\
\hline Erythromycin & + & - & + & - & + & + & + & - & - & - & - \\
\hline Sparfloxacin & - & - & - & - & - & - & - & - & - & + & + \\
\hline Chloramphenicol & - & - & - & - & - & - & - & - & - & + & - \\
\hline Augmentin & - & - & - & - & - & - & - & - & - & + & - \\
\hline Tarivid & - & - & - & - & - & - & - & + & - & + & - \\
\hline
\end{tabular}


Table 4. Effect of antimicrobial agents (antiseptic and disinfectant) on bacterial isolates from inside and outside the laboratory

\begin{tabular}{|c|c|c|c|c|c|c|c|c|c|c|c|}
\hline Agents & 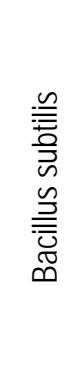 & 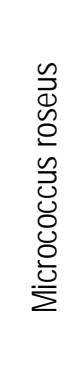 & 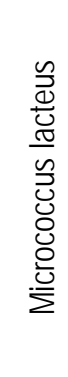 & 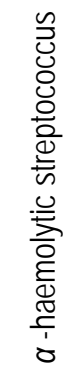 & 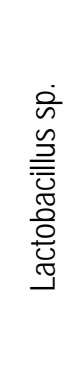 & 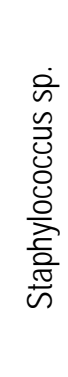 & 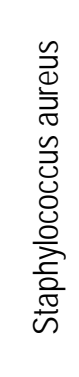 & 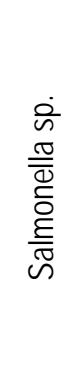 & 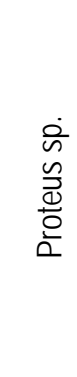 & 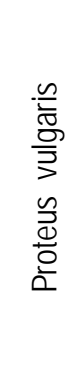 & نे \\
\hline Ethanol & + & - & - & + & - & - & + & - & + & + & - \\
\hline Izal & + & + & + & + & + & + & + & + & + & + & + \\
\hline Jik & + & - & + & + & + & - & + & + & + & + & + \\
\hline Dettol & + & + & + & + & + & + & + & + & + & + & + \\
\hline $\begin{array}{l}\text { Hand } \\
\text { sanitizer }\end{array}$ & - & - & - & - & + & - & + & - & + & - & - \\
\hline
\end{tabular}

+ = susceptible =, - = resistant

\section{Discussion}

Bacteria isolated from outside the laboratory were found to be more than those isolated from inside the laboratory. This observation is in agreement with the findings of a number of earlier studies (Prussian and Marr 2015, Klaric and Pepeljnjak 2006) which reported that the composition of aerial microbes is determined by several factors amongst which are seasonal meteorological differences, vegetation and air pollution arising from human activities. Nazaroff (2014), Chen and Zhao (2011) and Lehtonen et al. (1993) reported that a very large percentage of the indoor aerial microbial contaminants are from outdoor source. In this present study, it was observed that the bacteria isolated from the laboratory in the morning before the day's activities and those isolated from outside the laboratory were all gram positive bacteria namely members of the genera Micrococcus, Staphylococcus, Bacillus, Streptococcus and Lactobacillus. Muhammad et al. (2017), Shaffer and Lighthart (1997) and Mancinelli and Shulls (1978) reported earlier that the most common airborne bacteria belong to the genera Bacillus, Micrococcus, Staphylococcus, and Pseudomonas. The preponderance of Gram positive bacteria may not be unconnected with their spore forming nature as a result of which they may be suspended in the air for several hours and even few days. Spores are intrinsically hardy and are widely distributed in the environment (ljah and Abioye 2003).

On the other hand, the organisms isolated from the laboratory in the evening comprised both Gram positive and Gram negative bacterial genera such as Salmonella, Proetus, and Escherichia. Their presence in the laboratory during this study could have been as a result of contamination arising from the activities of the people in the laboratory, outdoor sources or from rodents such as rats or mice that normally hang around within the laboratory to feed on leftover samples. Lehtonen et al. (1993) reported that microbial contamination could be from the occupants themselves, their activities as well as indoor plants. Each of the 
bacteria identified except $E$. coli exhibited resistance to two or more of the antibiotics tested which might be as a result of genetically acquired resistance. The presence of these microbes in the laboratory could have serious health implication for the students and the staff occupying the laboratory. Some of the microorganisms are well documented causative agents of urinary tract infections (E. coli, Proteus sp.), skin infections (Staphylococcus aureus) and gastrointestinal infections (Salmonella sp.). All the bacterial isolates were sensitive to the antimicrobial agents (antiseptics and disinfectants) as these agents successfully inhibited the growth of the organisms. The organisms were however resistant to all the hand sanitizer tested. This observation may be attributed to the low concentration of the antimicrobial agents in the hand sanitizer.

\section{Conclusion}

This study has led to the isolation of different pathogenic microorganisms from the laboratory environment. These strain demonstrated high sensitivity to the tested antibiotics and antimicrobial agents. Therefore, it could be concluded that regular cleaning of the laboratory using some of these disinfectants should be practiced to safeguard people especially staff and students from contracting infections while working in the laboratory.

\section{References}

Abarca M, Bragulat M, Castella G and Cabanes F (1994). Ochratoxin a production by strains of Aspergillus niger var. niger. Applied Environmental Microbiology, 60(7): 2650-2652.

Adams RI, Miletto M, Lindow SE, Taylor JW and Bruns, TD (2014). Airborne bacterial communities in residences: similarities and differences with fungi. PLoS One, 9: e91283.

Burge HA, Solomon HR and Muilenberg ML (1982). Evaluation of indoor plantings as allergen exposure sources. Journal of Allergy and Clinical Immunology, 70: 101-108.

Campbell MC and Stewart JL (1980). The Medical Mycology Handbook. A Wiley Medical Publication, New York, pp. 1436.

Cheesbrough M (2009). District laboratories practice in tropical countries. $2^{\text {nd }}$ Edition Cambridge University Press, Cambridge, UK, pp. 1-440.

Chen $C$ and Zhao B (2011). Review of relationship between indoor and outdoor particles: I/O ratio, Infiltration factor and penetration factor. Atmospheric Environment, 45: 275-288.

Cowan ST (1974). Manual for the identification of medical bacteria. Cambridge University Press, Cambridge London: 444-463.

Douwes J, Thorne P, Pearce N and Heederik D (2003). Bioaerosol health effects and exposure assessment: progress and prospects. Annals of Occupational Hygiene, 47: 187-200.

Ekhaise FO, Ighosewe OU and Ajakpori OD (2008). Hospital indoor airborne microflora in private and government owned hospitals in Benin City, Nigeria. World Journal of Medical Sciences, 3(1): 34-38.

El-Morsy ESM (2006). Preliminary survey of indoor and outdoor airborne microfungi at coastal buildings in Egypt, Aerobiologia, 22: 197-210.

Holdbrook R (1982). Oxoid Manual of Culture Media, Ingredients and other Laboratory Services (5 $5^{\text {th }}$ Edition), pp. 52-55.

ljah UJJ and Abioye OP (2003). Assessment of physicochemical and microbiological properties of soil 30 months after kerosene spill. Journal of Research in Science and Management, 1(1): 24-30.

Klaric MS and Pepeljnjak S (2006). A year-round Aero mycological study in Zagreb Area, Croatia. Annals of Agricultural and Environmental Medicine, 13: 55-64. 
Lehtonen M, Reponen T and Nevalainen A (1993). Everyday activities and variation of fungal spore concentrations in indoor air. International Biodeterioration and Biodegradation, 31: 25-39.

Mancinelli RL and Shulls WA (1978). Airborne bacteria in an urban-environment. Applied and Environmental Microbiology, 35:1095-1101.

Mitchell BW and King DJ (1994). Effect of negative air ionization on airborne transmission of Newcastle disease virus. Avian Disease 38 (4).

Naruka K and Gaur J (2014). Distribution pattern of airborne bacteria and fungi at market area. American-Eurasian Journal of Scientific Research 9(6): 186-192.

Nazaroff WW (2014). Indoor bioaerosol dynamics. Indoor Air, doi:10.1111/ina.12174.

Nocker A, Fernandez PZ, Montijn R and Schuren F (2012). Effect of air drying on bacterial viability: A multi-parameter viability assessment. Journal of Microbiological Methods, 90(2): 86-95.

Piters AAS, Sanders EAM and Boggaert D (2015). The role of the local microbial ecosystem in respiratory health and disease. Philosophical transactions of the Royal Society of London. Series B, Biological Sciences, 370 (1675).

Prussin AJ and Marr LC (2015). Sources of airborne microorganisms in the built environment. Microbiome, 3(78): 1-10.

Reponen T, Lehtonen M and Raunemaa T (1992). Effect of indoor sources on fungal spore concentration and size distribution. Journal of Aerosol Science, 23(1): 663-666.

Shaffer BT and Lighthart B (1997). Survey of culturable airborne bacteria at four diverse locations in oregon: Urban, Rural, Forest, and Coastal. Microbial Ecology, 34: 167-177.

Solomon FB, Wadilo FW, Arota AA and Abraham YL (2017). Antibiotic resistant airborne bacteria and their multi drug resistance pattern at university teaching referral hospital south Ethiopia. Annals of Clinical Microbiology and Antimicrobials, 16(29): 1-7.

Tsai FC and Macher JM (2005). Concentrations of airborne culturable bacteria in 100 large US office buildings from the BASE study. Indoor Air, 15(9): 71-81.

Wolfgang L, Wesley EK and Wolfgang L (2002). Plasmid-borne macrolides resistance in Micrococcus luteus. Microbiology, 148: 2479-2487.

Zhiguo F, Zhiyun O, Hua Z and Xiaoke W (2008). Concentration and size distribution of culturable airborne microorganisms in outdoor environments in Beijing, China. Aerosol Science and Technology, 42: 325-334. 